\title{
Development of Collecting at the Milingimbi Mission
}

\author{
Louise Hamby with Dr Gumbula \\ The Australian National University
}

By the time Ian Keen purchased a few bark paintings there in the mid-1970s, the collection of material culture at Milingimbi had already been underway for half a century, from its very earliest days as a Methodist mission. It has hosted a steady stream of visitors, art collectors, anthropologists, and others since those early days. They went to Milingimbi with a wide variety of purposes, but the collections they made integrate them together into the story of Milingimbi. Some of these collections remained together and others were dispersed immediately; some are relatively small and private and others are prominent parts of internationally recognised museums. As Satterthwait notes, 'In essence, the process by which museum collections come into being reflects the outcome of a sequence of selective events, some deliberate and systematic and others opportunistic and highly contingent' (Satterthwait 2008: 42). Perhaps most importantly, the meanings of collections and their objects are not fixed, and are interpreted differently in different historical periods and by members of different cultures. A critical examination of the collection of material culture from Milingimbi, then, can reveal a great deal not only about Yolngu society and how it has changed over the last century, but also about the shifting impulses and motivations of the collectors themselves.

Satterthwait notes that collections are themselves artefacts even as they are composed of them, and the associations linking things together give collections a meaning beyond their individual elements (ibid.: 29). He also notes that all collections are structured in a variety of ways, which could include type of object, techniques of production, function, place of origin, and contextual 
meanings (ibid.: 31). Importantly, Satterthwait also asks what degree of spatial proximity is necessary for objects to be considered a 'collection', given that widely dispersed materials located in museums around the world may form a 'distributed collection' (ibid.: 46-7), especially in the Internet age. Given all of these considerations, we may define collections as 'social artefacts consisting of individual elements connected by webs of socially engendered meanings' (ibid.: 48).

With this in mind, recent engagement by Aboriginal people with ethnographic collections may be seen to represent a new kind of collection-making, in a process of cultural reclamation spanning material objects dispersed in museums around the world. In contemporary life in Arnhem Land today, Yolngu are seeking ways of reaffirming their identity and taking an active role in how they are perceived by others, and the reinterpretation of items collected by others over the past century plays an important role. Paintings and other objects not only 'tell people who they are' (Corn and Gumbula 2006: 190), but are key to the mediation and transmission of knowledge to younger generations today and to balanda (outsiders). In the broad sense outlined by Satterthwait above, these acts of examining, reclaiming, and reinterpreting material objects relevant to Yolngu cultural identity constitute Yolngu collection-making, regardless of the physical location of the objects themselves or who collected them.

This chapter will focus on collections from Milingimbi as a means of investigating the motivations behind collecting and other issues concerning identity, agency and power relations. Ethnographic collecting as an activity has changed over time in Australia, and five collecting periods have been classified based primarily on the motivations behind their formation: unsystematic collecting (contact to c. 1880); collecting under the influence of social evolutionary theory (c. $1880-$ c. 1920); collecting under the influence of a philosophy of obtaining materials 'before it is too late' (c. 1920-40); research adjunct collecting (c. 1940-80); and predominantly secondary collecting (c. 1980 - present) (Peterson, Allen, and Hamby 2008: 8-10). Milingimbi enters into this type of classification in the third period of salvage ethnography influenced by structural functionalism, and accounts for a significant amount of the material from Milingimbi. The collections examined in this chapter end with the fourth period, c. 1940-80, even though the last period of collecting extends to the present day. Collections made in all periods are now in the process of critical reassessment, and there is a shift in museum practice that gives recognition to the authority of the original makers and their descendants that shifts the power balance. Importantly, we can also recognise that, regardless of the time frame and motivations for the original collecting activities, the resulting collections of material culture may be interpreted according to a radically different set of culturally specific criteria which may convey previously unrecognised meanings. 


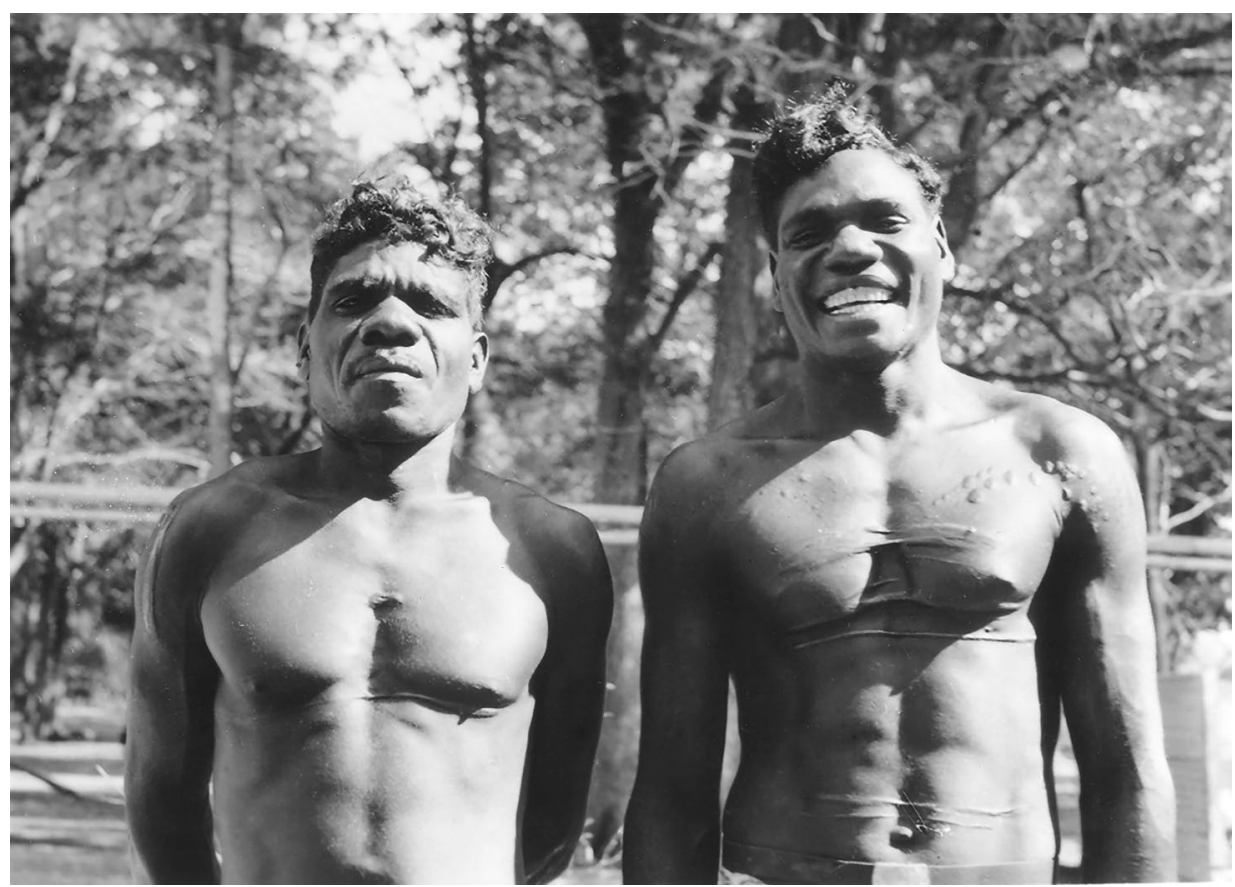

Figure 9.1 Djäwa and Wulili from Goulburn Island, c. 1926-39.

Source: Rev. T.T. Webb. Courtesy University of Sydney Archives.

The idea that some objects of material culture may be subject to contested and shifting interpretations may be relatively new in museum studies, but it is not for Yolngu people, a point that Ian Keen's scholarship has demonstrated time and again. From his first article, 'Ambiguity in Yolngu Religious Language' (Keen 1977) to Knowledge and Secrecy in an Aboriginal Religion (1994) and beyond, Keen has argued that systematic ambiguity is an inherent feature of Yolngu myth and religious practice, and that the interpretation of madayin is a political act. It was fitting, then, that Dr Gumbula ${ }^{1}$ (1954-2015), the son of one of Keen's main informants, Djäwa Daygurrgurr (1905-80), was a key player in the Yolngu reinterpretation of materials collected by his forebears. In his extended study of Yolngu cultural materials in museum collections around the world, especially those pertaining to his own Gupapuyngu group, we can see the active and politically empowering process of forming new 'legacy collections' by linking items through Yolngu 'webs of socially engendered meanings'.

1 In accordance with the wishes of his family, and in recognition of Yolngu cultural protocols concerning the recently deceased, 'Dr Gumbula' will be used as a term of reference throughout this chapter in place of the co-author's Yolngu name. 


\section{Milingimbi the Place}

The decision by missionaries to start a mission at Milingimbi proved to be the pivotal point in time for the formation of legacy collections of material culture, that is, collections handed down by previous generations. Also known as Yurruwi, Milingimbi is one of the largest islands in the Crocodile Islands group, and at the time of missionisation 'had a reputation as a meeting ground for the preparation and ultimate staging of great Aboriginal ceremonial rituals' (E. Wells 1982: 5). Its physical nature is quite different from the Methodist mission stations of Elcho Island and Goulburn Island, being quite flat. It is off the mainland of Arnhem Land between the Glyde and Blyth Rivers, approximately 25 kilometres away from the closest mainland Arnhem Land community, Ramingining. Mangrove and tidal mud flats divide the island into many sections. In addition to the mangroves, there are a great number of tamarind trees, an inheritance from Maccassan trepangers who found Milingimbi to be an excellent place for their activities.

Milingimbi was a centre for Macassan trepang gatherers because of its permanent waterhole and fine beach. For similar reasons Milingimbi was a ceremonial centre for the Yolngu; several hundred could gather at the permanent waterhole towards the end of the dry season to exploit the abundant cycad-palm nuts in the forest, and rush-corms and long-necked turtles from the plains and lakes. (Keen 1978: 16)

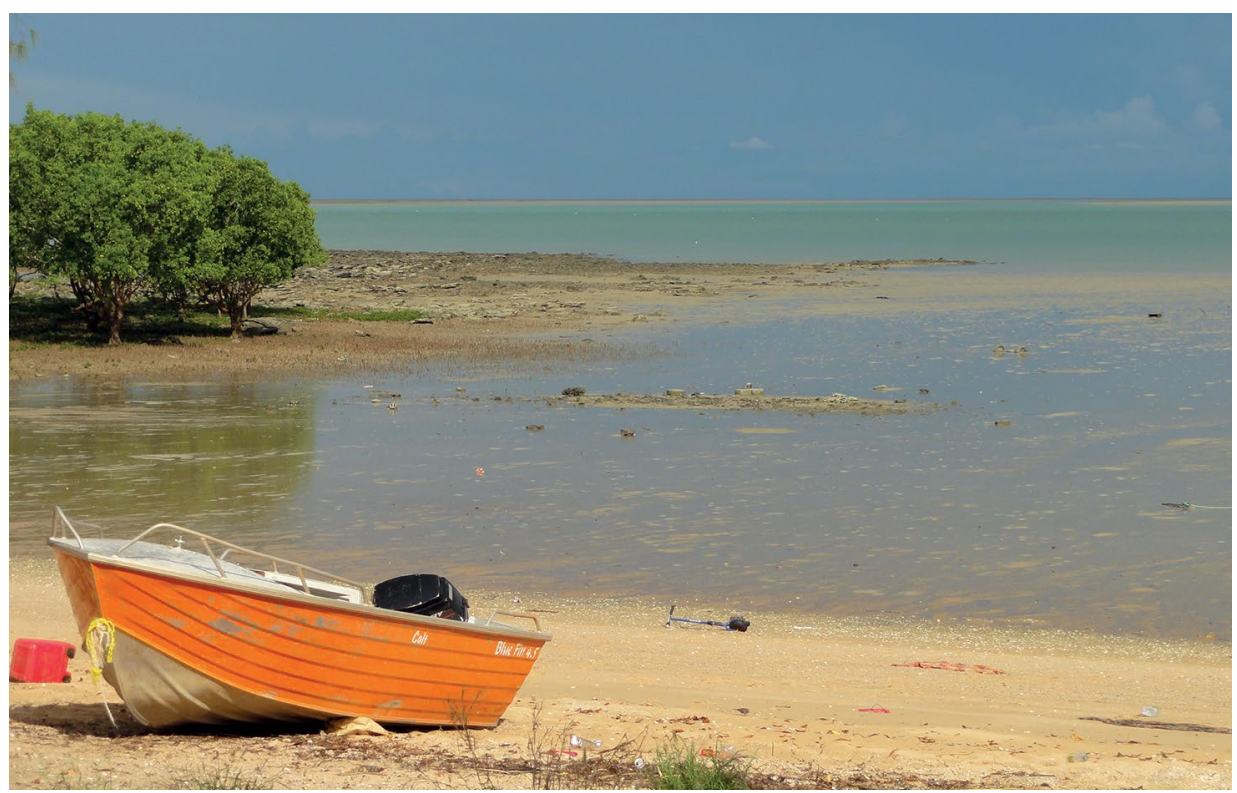

Figure 9.2 Beach at Top Camp, Milingimbi, 2013.

Source: Louise Hamby. 
In addition to the flat low country that was ideal for collecting trepang, the presence of the Macassan visitors was important for Yolngu in the selection of a mission site. Different Yolngu groups had established a pattern of engagement and trade with the Macassans for items that they wanted. The exchange of labour for the processing of trepang was matched with cloth, tobacco, rice and other goods. Yolngu familiarity with this process of trading made it easier to come to an understanding with mission ways of dealing with people with respect to their work for the mission. The Macassan background engagement with Milingimbi was a cultural reason for the establishment of the mission.

Rev. James Watson (1865-1946), who was appointed as the first missionary to Milingimbi in 1923, described it in a positive manner: 'It is an emerald set in a sapphire sea' (McKenzie 1976: 28). Later people were not so positive in their description. The missionary T.T. Webb's opinion, recounted by Gracie McKenzie, was quite different.

He saw the rivers as 'winding channels, cut through the primaeval mud and slime, swarming with crocodiles, and walled in all the way by dense mangrove swamps, with a tidal rise and fall of from 15 to 20 feet ... Altogether depressing, beyond all description' (McKenzie 1976: 43)

Aboriginal people from many clans have lived for a long time on the main island and surrounding islands, including nearby Murrunga Island in the Arafura Sea. The establishment of the mission brought with it things that people desired, such as rations and tobacco, and thus brought together people who were not always at peace with each other. The main Dhuwa-moiety tribal and clan groups are Liyagalawumirri, Manarrngu, Ngaymil, Buyugulmirri, Djambarrpuyngu, Gälpu, Marrangu, Gamalangga, Gorryindi, and Malarra. Yirritja-moiety groups are Gupapuyngu, Warramiri, Wangurri, Wubulgarra and Birrkili (ALPA 2009).

\section{Collectors in the Third Phase of Collecting, c. $1920-40$}

The first collector in the third phase of collecting, characterised by the philosophy of obtaining materials 'before it is too late', was Sir Hubert Wilkins (1888-1958). He was commissioned by the British Museum of Natural History to make a collection of flora and fauna from the northern portion of Australia during 1923-25 to fill in the gaps in the museum's collection. Although not part of his brief, and although salvage ethnography was not an explicitly stated aim, he collected objects of material culture from Queensland, Groote Eylandt and from Milingimbi. While at Milingimbi (August to December 1924) he accompanied James Watson on the mission lugger. On nearing Elcho Island, 
a group of Aboriginal men paddled out to the lugger and 'traded turtle-shell for tobacco, cloth, and blue glass beads' (Wilkins 1929: 130). His collection of ethnographic items in the British Museum contains 30 labelled objects, one being a large group of armbands. Other items include bodywear, containers, clapsticks and yidaki. His material culture collecting followed his scientific approach to the extent that he used the same labels for objects as he did for animals. Wilkins's photographs from Arnhem Land through this period are significant to contemporary Yolngu, and some of these photographs appear in his book Undiscovered Australia (1929).

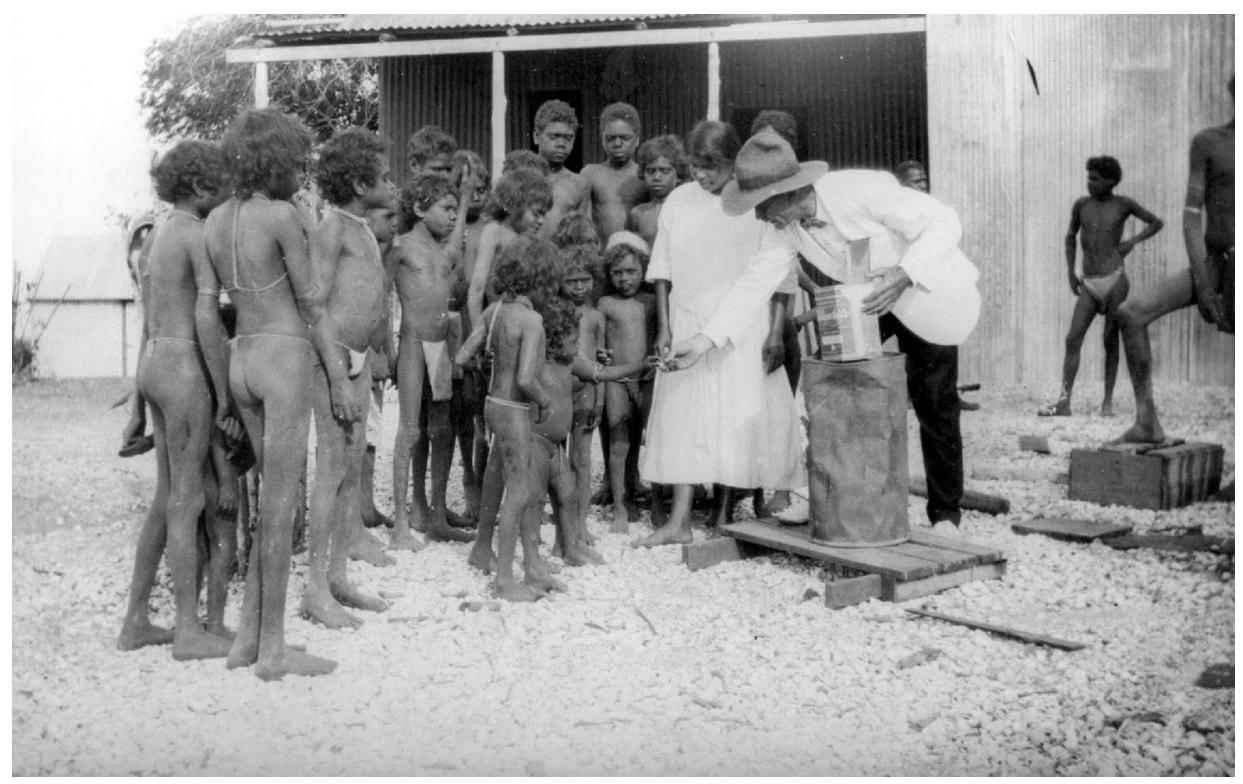

Figure 9.3 Rev. James Watson distributing food to children assisted by Rosie from Goulburn Island, wife of Andrew Birrinydjawuy Garawirrtja, Milingimbi, 1924.

Source: Hubert Wilkins, Courtesy of Byrd Polar Research Center, The Ohio State University. Wilkins32_14_39.

Thomas Theodor Webb (1885-1948) arrived in 1926 with his wife, Evelyn Mary, to replace James Watson, who retired a sick man in January 1926 (McKenzie 1976: 1). The Methodist Missionary Society of Australasia had made Webb superintendent of Milingimbi station, and chairman of the North Australia District. In 1928 the Milingimbi team grew with the addition of the lay missionaries Harold (1903-2000) and Ella Shepherdson, who arrived in the Northern Territory in 1927. The Shepherdsons were to become the longestserving husband-and-wife team in Arnhem Land: they stayed at Milingimbi until World War II intervened, and on 22 June 1942 they moved to Elcho Island and remained there until they left Arnhem Land in 1977 (Shepherdson 1981). 
In addition to their primary tasks as missionaries, Webb and Shepherdson also made collections of material culture while they were at Milingimbi. As was the case with Wilkins, collecting was not their primary purpose for being at Milingimbi. Webb was a strong leader and advocated for Aboriginal people to maintain most of their cultural practices, and was an unusual missionary in that he was very interested in anthropology and had a desire to understand Yolngu culture. 'Webb would accept the preservation of Yolngu customs not deemed intrinsically oppositional to the missionary way of life' (Risemen 2008: 249-50). This attitude helped considerably in the collection of material culture items. By being allowed to maintain their ceremonial life, Yolngu people produced objects that were sought after by museums in the south, and were also a means for Webb to understand cultural practices. He was more interested in objects than art, as demonstrated by the fact that only two bark paintings were sent to Museum Victoria. Webb also paid people for everyday items that he collected and sold as well. He was considered to be 'the most profound thinker of the mission in his era, and the most anthropologically informed' (Kadiba n.d.). He contributed many articles to the journals Missionary Review and Oceania and published two books about his experiences in Arnhem Land. Webb made a substantial collection from Milingimbi. The majority of this work is held in Museum Victoria in Melbourne (around 400 objects), while another significant portion is at the Museum der Kulturen in Basel.

Shepherdson had a vision of Aborigines living on their own country away from the large mission settlements, and flew his own plane to these small settlements to collect artefacts and deliver rations. He could be called 'the prophet of the homelands movement' (Cole 1979: 113). He and his wife were not as prolific as Webb in their documentation of events, but as a team they produced photographs and Ella wrote a diary that was developed later into the book Half a Century in Arnhem Land (1981). Although the Shepherdsons were not academically inclined, they had the welfare of Yolngu at the heart of what they did. The rationale for their collecting must have been in a great part to generate income for both the artists and for the mission, very much like that of Webb. Yolngu were paid for making objects, and the mission also received a percentage of the sale of these items to museums. The Shepherdson Collection numbers over 700 items acquired during their time in Arnhem Land, and is now located in the South Australian Museum. The group of objects contains items both from their time at Milingimbi and their years spent on Elcho Island. Many items that were collected by the missionaries and sold to museums were of a ceremonial nature, used in practices about which the missionaries were ambivalent: the missionaries tolerated these ceremonies as long as they did not directly contradict their teaching and they were able to obtain the items to boost income for the mission. 


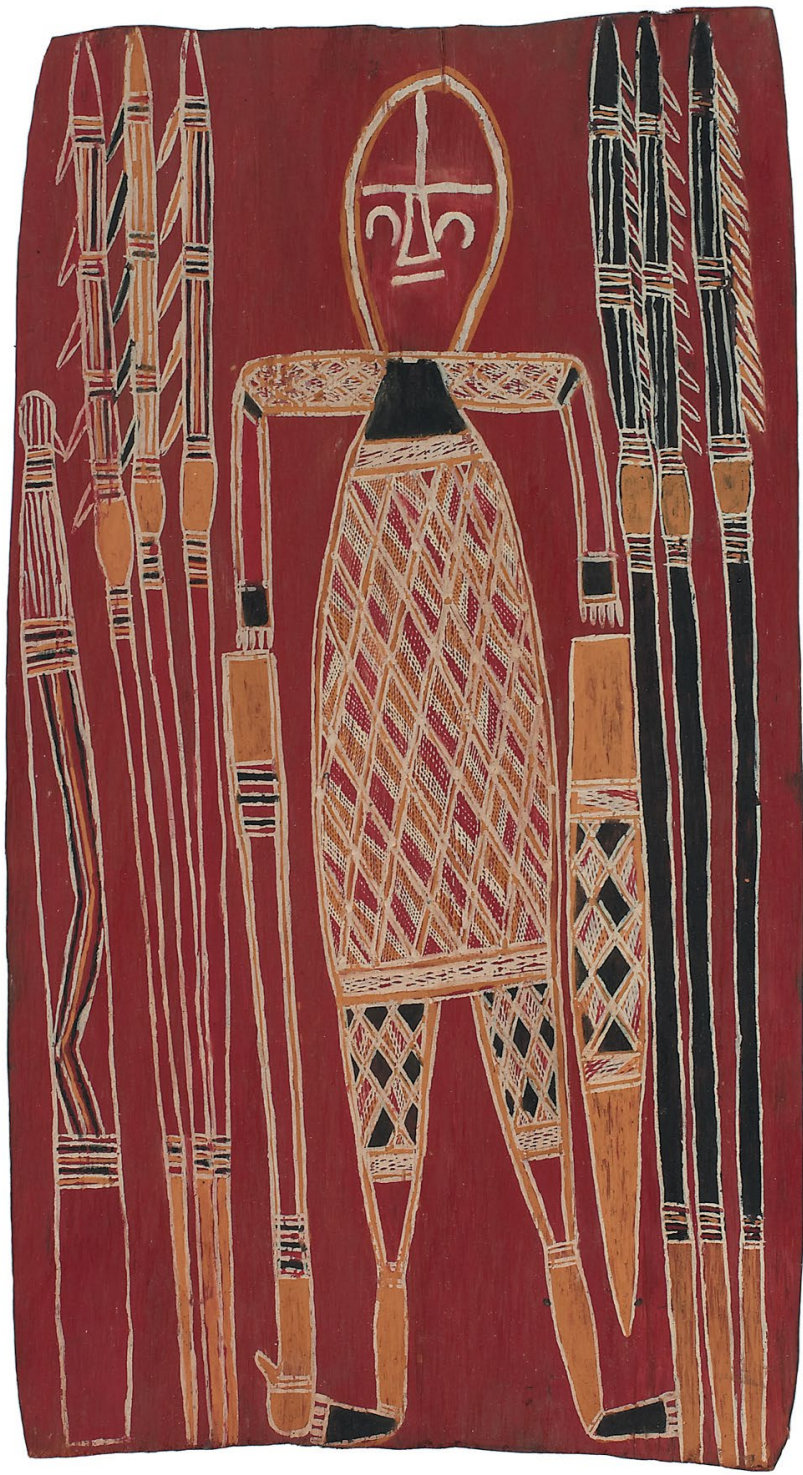

Figure 9.4 Murayana by Djäwa Daygurrgurr.

Source: Collected by Edgar Wells. Courtesy of Museum Victoria.

The American anthropologist William Lloyd Warner (1898-1970) arrived in 1927 to conduct research centred around the social structure and totemic beliefs of the people in Milingimbi and the surrounding area (Warner 1969). In the process of this work, and secondary to his prime objectives, he made a collection of artefacts. At Berkeley, Warner had been surrounded by and taught 
by students of Franz Boas, including Robert H. Lowie and Alfred Kroeber. Warner made a substantial collection that was dispersed across nine institutions and two countries, and which includes containers, mats, paintings, weapons, ceremonial objects, items worn on the body, photographs, objects and sound recordings. The time of Warner's research was a transition between diffusionism and functionalism in anthropological theory that saw a decline in the significance of artefacts as data. Warner's mentors, Malinowski and Radcliffe-Brown, did not view objects as an important part of the social order. It is not certain if Warner was motivated by salvage ethnography, collecting before the items were no longer made; more likely, he collected as part of his obligations to the University of Sydney and his grant. In the functionalist view advocated by Lowie and others, artefacts were relevant mainly to the anthropologist's local findings. He did not write about any particular motivations for his collecting practices; it appears that he did not seek out particular examples of material culture, but rather obtained what was at hand.

After Warner left Milingimbi another famous anthropologist who worked across Arnhem Land visited the island. Donald Thomson first trained as a scientist before studying anthropology at the University of Sydney. Thomson went to Milingimbi several times, the first visit being in July 1935 when he stayed for two months, and then going back for similar periods in 1936 and 1937. Thomson was skilled in many areas, including photography and languages. These abilities, coupled with his successful working relationships with Yolngu, enabled him to collect over 5,000 objects and 2,500 photographs from across Arnhem Land. The Thomson Collection has 240 items specifically identified as being from Milingimbi. Beyond the desire to amass materials, he sought to collect a representative selection of both everyday and ceremonial objects at the time; perhaps, according to Allen, it was an attempt to preserve the culture (Allen 2008: 400), and in that respect he was collecting 'before it was too late'. His background as a scientist influenced his collecting practices in that he would be very familiar with characteristics that would help to classify a specific object.

\section{Collectors in the Fourth Phase of Collecting, c. $1940-80$}

The fourth phase of collecting is primarily known as adjunct collecting, meaning that it was usually undertaken alongside another major area of research or activity. This was the kind of collecting practised by missionaries, whose primary focus was not collecting. Rev. Arthur F. Ellemor (1906-80) was 
at Milingimbi from 1939 to 1949, including during the war years when Ellemor remained at Milingimbi while Shepherdson went to Elcho Island. Keeping people alive during the war was a primary concern, but Ellemor also collected some objects, 19 of which are at the University of Queensland Anthropology Museum. The majority of these entered the collection after the war.

Edgar Wells, superintendent from 1949 to 1959, was known as a patron of the arts at Milingimbi. His collecting may have been adjunct to his role of being a missionary, but he was strongly motivated to collect art, as he had a personal interest in art as well as an anthropological one that involved drawing people to the mission. Wells not only collected paintings for the mission to sell to museums, but also made a personal collection of bark paintings. He comments about bark painting at the time:

Encouragement of the arts attracted interest over a very wide area of Arnhem Land and Djawa, at that time manoeuvring to become ceremonial leader at Milingimbi, used this interest to his own advantage and invited clan leaders from other areas to visit Milingimbi and take part in various ritual activities. (E. Wells 1982: 69)

Djäwa was an accomplished artist and produced many paintings that attracted the interest of Wells. The personal collection of Edgar Wells from his time as a missionary during the 1950s now resides at Museum Victoria. On reflection, Ann Wells saw this relationship with the men as being formative in many ways at the mission:

The trade that really became the channel for understanding between my husband and the adult men was their art work. He became so interested in it that he procured books and read widely on the subject of primitive art. He soon grew able to meet the men on a common ground when they were interpreting their beautiful paintings for him. I wish now I had some photographs of his Saturday morning 'native affairs' as we called them. Dainanan and Yilgari, Jawa, Dawawangulili and Magani, and other artists as they moved in and out of the station, would meet in the dim coolness and sanctuary of the store.

(A. Wells 1963: 136) 


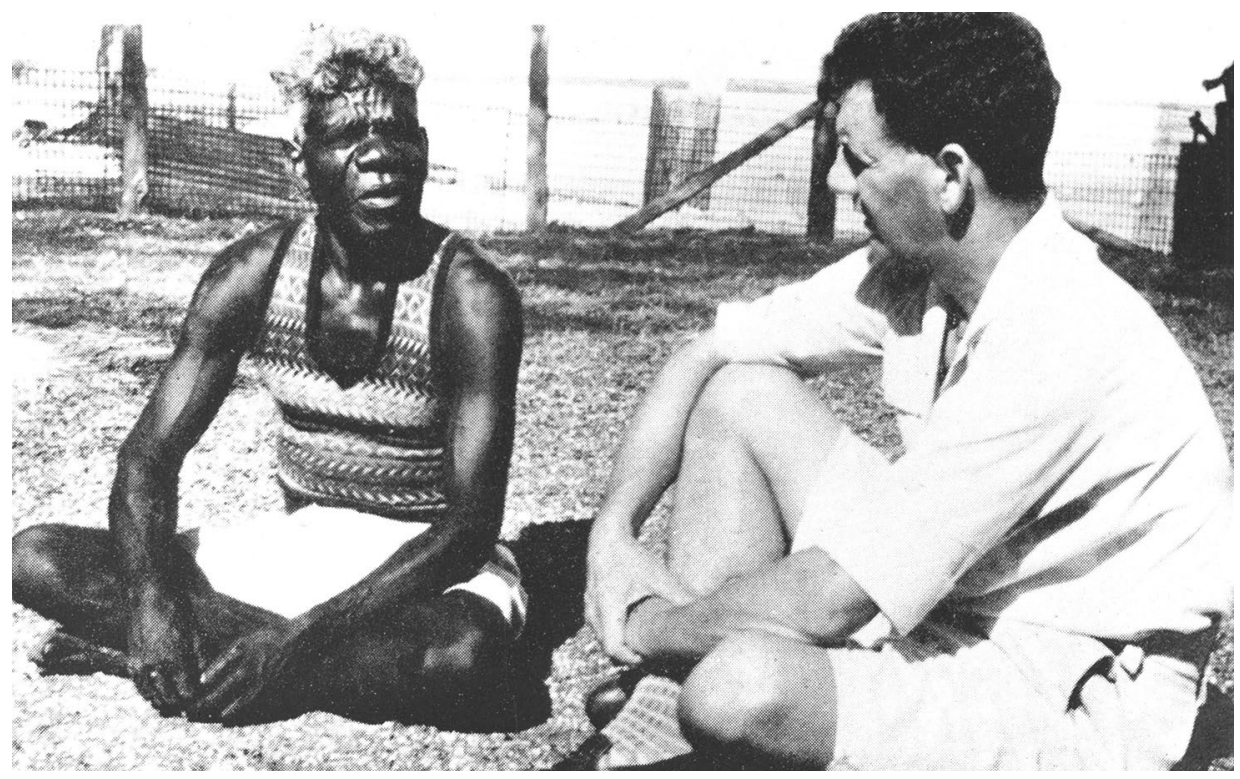

Figure 9.5 Djäwa Daygurrgurr and Edgar Wells at Milingimbi, c. 1955.

Source: Beulah Lowe. Courtesy Kluge-Ruhe Collection, The University of Virginia. 6.01.09.002.

The material culture collecting of Ronald (1916-90) and Catherine Berndt (1918-94) supported their primary research on religious and social organisation. When they were in Milingimbi in May-June 1950 they collected paintings. In addition to Milingimbi itself, they also collected work from the mission store in Darwin, particularly in 1961 and 1964. Objects were collected later from their many visits to Darwin, and directly from Milingimbi Crafts when it was established (John Stanton, personal communication, 13 November 2012).

For some scholars during this period, collecting was not an adjunct activity but rather a primary one. When Helen Groger-Wurm came to Milingimbi in June 1967, her main purpose was to collect and document paintings. Included in her book Australian Aboriginal Bark Paintings and their Mythological Interpretation are a selection of Daygurrgurr Gupapuyngu paintings: three of Djäwa's paintings, one from Bonguwuy and seven belonging to Lipundja (Groger-Wurm 1973). Similarly, the collecting of Frederick McCarthy from the Australian Museum and Frank Setzler in July 1948 was not adjunct collecting at all (Setzler 1948). They were part of the American-Australian Scientific Expedition to Arnhem Land that had the collection of everything as its primary objective. McCarthy and Setzler had different ideas about collecting than the expedition leader, Charles Mountford, who was probably more in tune with the collecting aims of the previous phase of salvage ethnography 'before it was too late'. While Mountford often directed people what objects to make based on an idea of 'real' artefacts (those from the past), the Milingimbi team collected what was made or was available for use in everyday life rather than commissioned 
objects (Hamby 2011: 222). More than 130 items were collected at Milingimbi, and are now in the following institutions: the Australian Museum, the National Museum of Australia, the South Australian Museum and the National Museum of Natural History, part of the Smithsonian Institution in Washington, DC.

During the 1960s the marketing of the art work was done by the missionaries in addition to their other duties. Alan Fidock was the main person involved in this type of work at the time, arriving in Milingimbi in 1961 as a teacher, and staying on the island until 1970 when he took an active role as an arts manager, locating the first art centre shop underneath his house (Mundine 2004: 40). In 1967 a mud brick building was built as an art centre by the beach (McCulloch 2011). Many changes came about in 1972 that also saw a greater interest in collecting art. Ken Nowland was superintendent at the time, when the Methodist Overseas Missions was handed over to the Northern Synod of the Uniting Church. The government transferred its administration to Milingimbi Community Incorporated, transforming it from a mission station into a township.

During Nowland's time on the island the American collector Edward Lehman Ruhe (1923-89) first became interested in Aboriginal art. In 1965 he visited Australia as a Fulbright scholar, during which time he was a visiting lecturer in English at the University of Adelaide (Ruhe 1971a). Although he did not go to Milingimbi at that time, he did make almost daily visits to the collection of Geoffrey Spence, which was housed in a municipal building within the Botanical Gardens in Darwin (Smith 2008: 560). He subsequently continued his research on bark paintings and communicated with many people in Australia, including previous staff at the Milingimbi mission. In 1966, Ruhe organised the purchase of half of Spence's collection, 130 paintings and more than 350 artefacts, some of which were from Milingimbi. Ruhe wrote many letters to B.A. Clarke, the assistant, and G.F. Symond, the chairman of the Methodist church in Darwin during 1971 to gain permission to work in Arnhem Land on his collection. In his letters he offered to volunteer:

It makes good sense to me to pay my own way and offer my services as a temporary mission worker with special interests and qualifications - the latter bound to be debatable, although I have supporters - and an additional willingness to accept any kind of mission chores for the sake of living close to the native community. (Ruhe 1971b)

For the Methodist church, the greatest problem for accepting Ruhe was a lack of accommodation. Permission was granted for him to spend two months at Milingimbi for purposes 'of scientific investigation of Aboriginal art and associated anthropological, sociological and individual patterns', as noted on his permit (Milliken 1972). He returned to Australia in 1972 to undertake this work at Milingimbi, meeting the artists, buying paintings, and taking photographs and film footage that he later made into a short documentary about bark painting. 
Some of the footage, which was later transferred to videotape, shows five artists painting in a grove of trees. Ruhe's notes identify the 'atelier of artists' as 'Burrungurr' (painting five Julungul in log), 'Boyun' (lily, snake, diver bird), 'Malangi' (two fish), 'Binyinyiwuy' (lizard and totem object) and 'Bonguwoi' (wurrpan and murayana, emu and ancestor spearing). (Smith 2008: 568)

Included in this sequence of film is Djäwa, wearing a purple T-shirt and sitting with these artists as the 'headman'. We also learn from this film that Djäwa adopted Ruhe (Herzmark 1972); indeed, it was a powerful relationship, one of märr mirri, having sacred power and carrying with it ceremonial obligations. This relationship had an impact on the work collected, influencing Ruhe to collect work from Djäwa and other Gupapuyngu painters. We can only assume this was a combination of the nature of the social relationship and the aesthetic appeal of the works themselves.

After the 1967 referendum, which recognised Aboriginal people as citizens, changes started to be made. In 1972 the Uniting Church appointed David Morgan as art and craft advisor, the first such dedicated position at Milingimbi. In 1973 the Australian Council for the Arts established positions of craft advisers in Arnhem Land communities. This position was held by Jurgen Groneberg during the mid-1970s. This title was later changed to art adviser. Djon Mundine came to this position at Milingimbi in 1979 before moving to Ramingining (Mundine 2000: 73). The system of having funded art centres with staff certainly had an impact on production of work and its appropriate attribution but is the topic of a much larger discussion.

\section{Yolngu Motivations and Reinterpretations}

The distinctive periods of collecting for the Milingimbi material represent Western ideas about the making of the collections and the intentions of outsiders. The Yolngu responses to collecting activities were probably quite different. It seems clear that Yolngu involvement in producing material culture for Western collections was motivated, at least in large part, by economic considerations. For example, James Watson was an exceptional man who gained the trust of the Yolngu, and whose relationship with Yolngu would play an important part in future dealings with other missionaries relating to collecting. This trust was achieved not only in his belief in a 'Great Creator Spirit' but by paying the artists for their work, first at Goulburn and then at Milingimbi. Richard Trudgen has observed that Watson's mission became a place where fair trade was practised, and men would travel for months with goods to trade. 'They could see that Bäpa (father/Reverend) Watson was a fair trader' (Trudgen 2000: 29). 
Yolngu motivations in being involved in the activities of Western missionaries, collectors, and scholars also revolved around the propagation and maintenance of specific Yolngu languages. The Methodist missionaries had to select one of the local languages in which to teach and to spread the gospel, one that would be widely understood in the region. The choice of Gupapuyngu satisfied this criterion, but also reflected the language affiliations of individuals who were prominent in community affairs and who had close relationships with the missionaries. Harry Makarwalla, who had been Warner's main informant in the late 1920s, was also the main helper at the mission and must have exerted some influence on the choice of Gupapuyngu, even though it was not the language originally spoken in Milingimbi before the mission was established. After his father died in the Wessel Islands, Makarwalla had been adopted by two of his märi (MMB), the Gupapuyngu brothers Narritjnarritj (father of Djäwa) and Waltjamirr, and so he would have supported the use of Gupapuyngu at the mission. This language choice continued with the work of the teacher and linguist Beulah Lowe (1927-2005), who came to Milingimbi in 1951. During her time she worked both with Baraldja, son of Harry Makarwalla, and with Djäwa, father of Dr Gumbula (Wearing 2007: 23, 87). Although Gupapuyngu is still widely spoken, Djambarrpuyngu, one of the languages of the Dhuwa moiety, has become the lingua franca in the community (Tamisari and Milmilany 2003: 2).

Edgar Wells also benefited from the fact that Makarwalla decided to work with him, bringing some continuity to the mission assistance. As noted earlier Makarwalla was assisted to this position of power by his Gupapuyngu supporters and because of his märi-pulu connection to country.

It was my very good fortune to have on Milingimbi as my first Aboriginal headman and general guide in Aboriginal affairs, Warner's principal informant, Mahkarolla, whom we came to know as Makawalla, and from him and his companions we learned to appreciate a little of the patterns of mind influencing the Aboriginal men of the area. (E. Wells 1982: 5)

Another important Yolngu motivation was educating outsiders about Yolngu life, a motivation that became more important as time passed in Milingimbi, often through performances and ceremonies that were filmed or photographed. A visit in 1954 by the Queen of England to Toowoomba highlighted this aspect involving performance. Betsy Wearing describes who from Milingimbi attended that event:

The following year when the Queen visited Australia a troupe of six men, including Djawa, Baraltja, Yipidi and Bungawui went to Toowoomba to dance for the Queen. Beulah was on furlough; she and her parents were proudly present. (Wearing 2007: 180) 


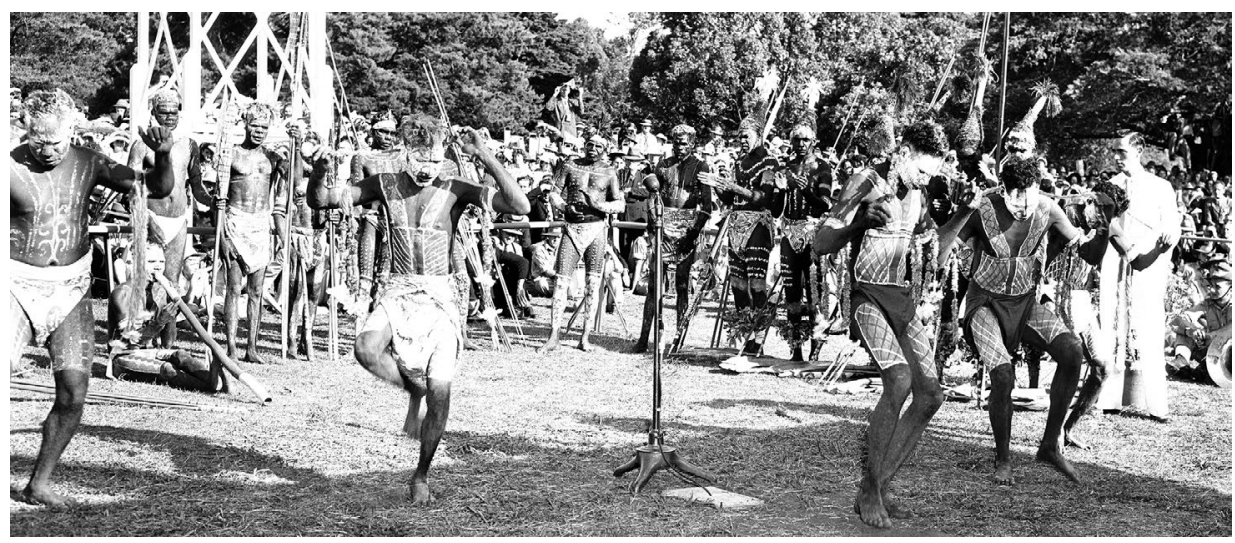

Figure 9.6 Arnhem Land dancers performing for Queen Elizabeth II and the Duke of Edinburgh at Toowoomba, 1954.

Source: Courtesy National Archives of Australia, A1773, RV1105.

Ann Wells writes about this event in terms of the preparation given to the men who were going; for the men it was a disquieting experience to see that many white people and to see the luxurious way of life, 'but for Jawa it was a treasured and instructive journey into a new world' (A. Wells 1963: 209). As with the contemporary reinterpretation of collections of material culture, this event is of importance to Gupapuyngu people today, particularly Djäwa's family. In July 2011 Zanette Kahler, manager at Milingimbi Art and Culture, brought a group of artists including John Damarrwura, Raymond Bulumbula, Wilson Manydjarri Ganambarr, and two of Djäwa's sons, Joe Dhamanydji and Dr Gumbula, to Brisbane for the Buku-Manupanmirr Exhibition and Bunggul. Afterwards, they went to Toowoomba to the showground to perform the same series of dances that Djäwa performed for the Queen ('Yolngu follow father's footsteps', 2011). Gumbula said, 'We could feel that by our imagination we were part of the story of Djäwa'.

The dances performed at Toowoomba both in 1954 and in 2011 were also held at Milingimbi in 1997 when the announcement was made of the death of Princess Diana. Daisy Baker (granddaughter of Makarwalla) and other Yolngu from the Gupapuyngu group danced white cockatoo, emu and brown hawk. These Gupapuyngu people were reasserting their position as leaders in the community by agreeing to perform. This type of performance had a history in the community with Djäwa holding leading roles in two documentary films directed by Cecil Holmes, Faces in the Sun (1963) and Djalambu (1964) (Corn and Gumbula 2007: 118). These performances concur with Tamisari's ideas about performance; as she writes, 'Dancing is one of the most effective ways of claiming, affirming and legitimising one's knowledge and authority in ceremonial contexts' (Tamisari 2005: 49). 
The same objects, documents and photographs, used by collectors for particular purposes, are viewed by Yolngu today with different perspectives and put to dissimilar uses. One example of this was Ruhe's use of catalogue cards. On his return to America, Ruhe worked diligently on his catalogue of bark painters, starting with the Milingimbi ones. On the cards he kept all the relevant information about each painter, and he communicated with people at Milingimbi, including Edgar Wells and Beulah Lowe, about appropriate spellings and correct information (Smith 2008: 569). In order to publish biographical information about the artists in his catalogue of works he collected as much data as possible on the cards from many sources. Indeed, these cards and other relevant documentation were of great interest to Dr Gumbula when he visited the collection in 2010. Gumbula was most concerned about the information that Ruhe had included on the card about his father, Djäwa. Gumbula wanted to know all the information gathered by Ruhe about his father; for him, the reading of the information reaffirmed Djäwa's position not only within the Gupapuyngu clan, but in the Milingimbi community and beyond.

A photograph taken by Donald Thomson was a key item in the reconstructing of the Daygurrgurr Gupapuyngu legacy and highlights the different intentions of 'collection makers' and the repurposing of collections by collection users. Thomson was interested in documenting life at the time; it was impossible to 'collect' everything, and photographs provided much information not only about objects, but about everyday and ceremonial life. Gumbula was seeking a photograph of Djäwa that depicted him with his famous shock of white hair, which is how he was remembered by most people of Gumbula's generation. The photo confirmed the identity of his father, but more importantly the place of his clan in ceremonial activity, as Thomson selected this Gupapuyngu activity to photograph. Eventually Djäwa was found in a photograph of a group of people, including Djäwa's father, Narritjnarritj, who were in the final stages of burial of Djäwa's grandfather. The Djalumbu film made in 1963, in which Djäwa stars, is a re-enactment of the Djalumbu ceremony for the final burial of Narritjnarritj (Corn and Gumbula 2007: 118). Gumbula's rationale for wanting the photograph was quite different than Donald Thomson's rationale for taking it, but he still appreciated the documentation of the ceremony.

When Ian Keen arrived in Milingimbi in 1974, it was a time of transition of authority, and Yolngu were determining their position in this new order. Keen worked with two leaders, one from each moiety, Djäwa and Bäriya. Djäwa was the accepted Daygurrgurr leader (liya-ngärra'mirri) at that time, and was also influential over others. 'A senior power-man like Djäwa has a measure of control over several clans' ceremonial life' (Keen 1978: 234). Indeed, Djäwa was the dalkarramirri song leader as well. In a description of a circumcision ceremony linked with the Daygurrgurr estate at Djiliwirri, Keen gives us another view 
of the person Djäwa. He quotes Djäwa: 'I have a lot of power, no one gets the better of me, white or black. I have the law for everyone. I am the elbow. I have the dalkarra, the power' (ibid.: 53). In a recent interview Keen reflected on leadership roles then and now and agreed that Gumbula was taking on that role. 'Djäwa was very much like [Dr Gumbula], very energetic and very similar in character' (Ian Keen, personal communication, 21 June 2012). Keen remembers that Djäwa and his brothers painted sacred work and would not let him look at those paintings, demonstrating a desire to control what items would be collected and by whom. Keen recalled that there was some carving of birds at the workshop. The mission was still in control of art at that time and they sometimes 'bumped up production when they were short of funds - to get money to eat' (ibid.) From this scenario it is easy to see that one motivation for the production of work was clearly an economic one on the part of Yolngu.



Figure 9.7 George Milaybuma, Matthew Baltha, lan Keen and Dr Gumbula at Djiliwirri, 2005.

Source: Louise Hamby.

For contemporary Yolngu, collections of artefacts are integrally linked to the ancestral estates to which they are connected, and the reinterpretation of such materials may be most meaningfully done on those estates. In July 2005, many of Djäwa's descendants (including Dr Gumbula), along with a number of researchers, visited the Daygurrgurr Gupapuyngu estate at Djiliwirri. Lindy Allen, senior curator from Museum Victoria, and Louise Hamby documented aspects of the Donald Thomson Collection. Aaron Corn and Ian Keen recorded a Gupapuyngu song cycle, Baripuy, over a one-week 
period. This manikay recounted the original observations of Murayana, a wangarr of the mokuy (ghost) class, who is also a subject in the series. These songs are also about the paperbark trees and the freshwater of Djiliwirri (Corn and Gumbula 2007: 117). Corn commented: 'From the earliest photograph of Thomson's shown to the youngest visitor among us, the family's presence at Djiliwirri spanned seven decades and six generations' (ibid.: 119). The visit highlighted the importance of the early collections like Donald Thomson's, but also demonstrated the continuing presence of the Gupapuyngu in the collecting practices and knowledge of balanda. The occasion was not merely one for balanda research, but was essential for the Gupapuyngu to reaffirm their position on their own country.

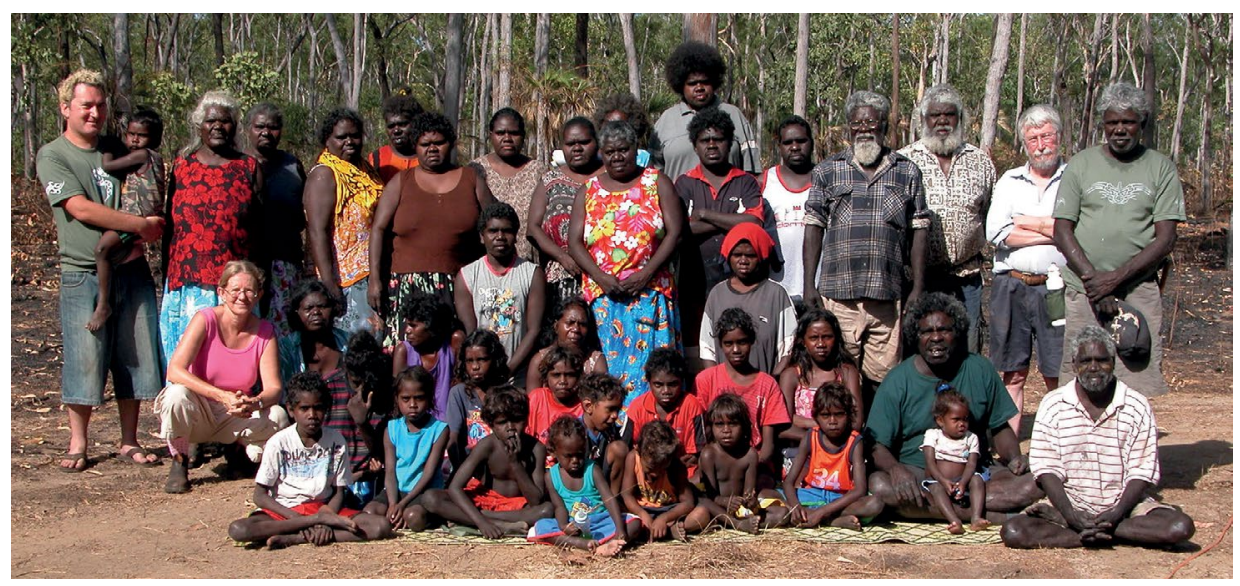

Figure 9.8 Gupapuyngu family and researchers including lan Keen, Aaron Corn and Louise Hamby at Djilwirri, 2005.

Source: Lindy Allen.

In 2010 Dr Gumbula, Pip Deveson and Louise Hamby embarked on a trip to the United States to document Gupapuyngu material culture in four museums: the Phoebe Apperson Hearst Museum of Anthropology at the University of California, Berkeley; the Peabody Museum of Archaeology and Ethnology at Harvard University in Cambridge, Massachusetts; the Smithsonian Museum of Natural History in Washington, DC; and the Kluge-Ruhe Aboriginal Art Collection at the University of Virginia in Charlottesville. Hamby had previously undertaken research at each of these institutions and knew what material would be of particular interest for the Gupapuyngu project. It is from the last institution particularly, the Kluge-Ruhe Collection, that we drew on some more recent examples, mainly those made in Gumbula's lifetime when he was a teenager or in his early 20s. As discussed above, Ruhe's collection contains many items from Milingimbi, ones which he collected himself in 1972 plus others bought from people such as Geoffrey Spence and Jim Davidson in the 1960s. 


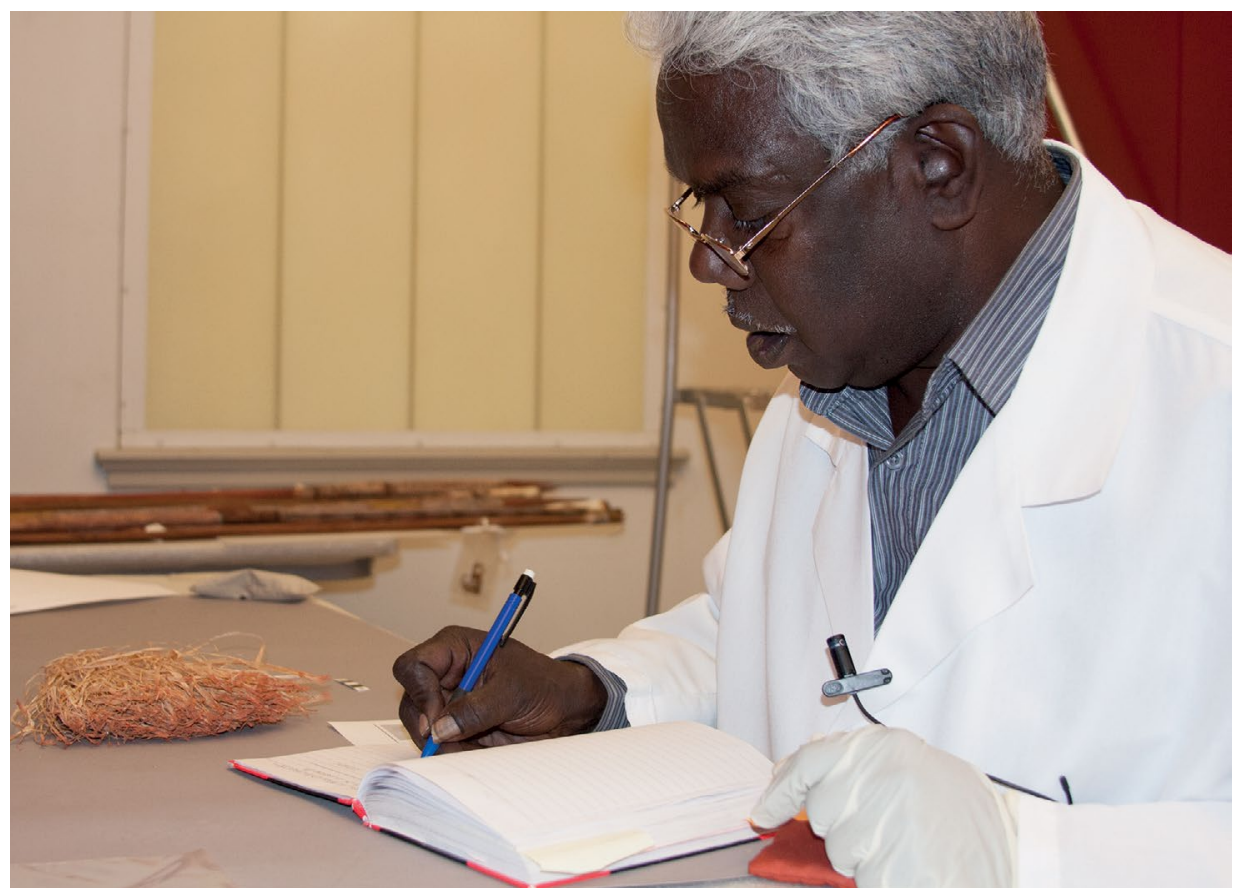

Figure 9.9 Dr Gumbula in a storeroom at The Peabody Museum of Archaeology and Ethnology, Harvard University, 2010.

Source: Louise Hamby.

Included in the items we examined in the collection were extensive archival materials, consisting of photographs, letters and mission records. Much time was spent looking at the Mission Register of Wards of all the people on the island in 1957. Djäwa's name was found on page 7, 'Jawa, born in 1905'. Many smiles came later when Gumbula said, 'I am here. That's me!' as he found himself listed on page 11 as Nibarnga, born in 1954. He was not so lucky when he saw a photo (11.03.02.019) of a man and child eating ice cream in wafer cones. 'The first ice cream; I remember this ice cream but my photo is not here.' Finding oneself or a relative either in a record or a photograph is always a satisfying moment and triggers many other memories. The absence of oneself in a documented event can show that the affiliation of the photographer may have belonged to another group of people that were captured on film. These records, and the paintings and objects, helped to fix a Gupapuyngu identity during the later years of the mission. Today the presence and absence of individuals in photographs or of particular works is often a source of concern for Yolngu, who may ask: 'Why wasn't my family depicted at this event?' Some groups may be represented partly on the basis of their relationship to the collector rather than the overall importance of an event or an object. During these early times representation in a collection was seen by some to be important and is manifested today. Being correctly 
documented provides a position in history. The importance of Djäwa as headman was reinforced with two photos (11.03.02.023 and 11.03.02.024) in the Ruhe Collection of what Gumbula described as an open court case in the community. In one photograph, the accused person, Ngalandirr, was seated on the ground. Seated on chairs at a table in front of him were Edgar Wells with Jacky Badaltja, son of Harry Makarrwala, on one side and Djäwa on the other as the headman. From discussions with Gumbula we learned that Jacky Badaltja is acting as the translator. Ngalandirr is on trial for murder.

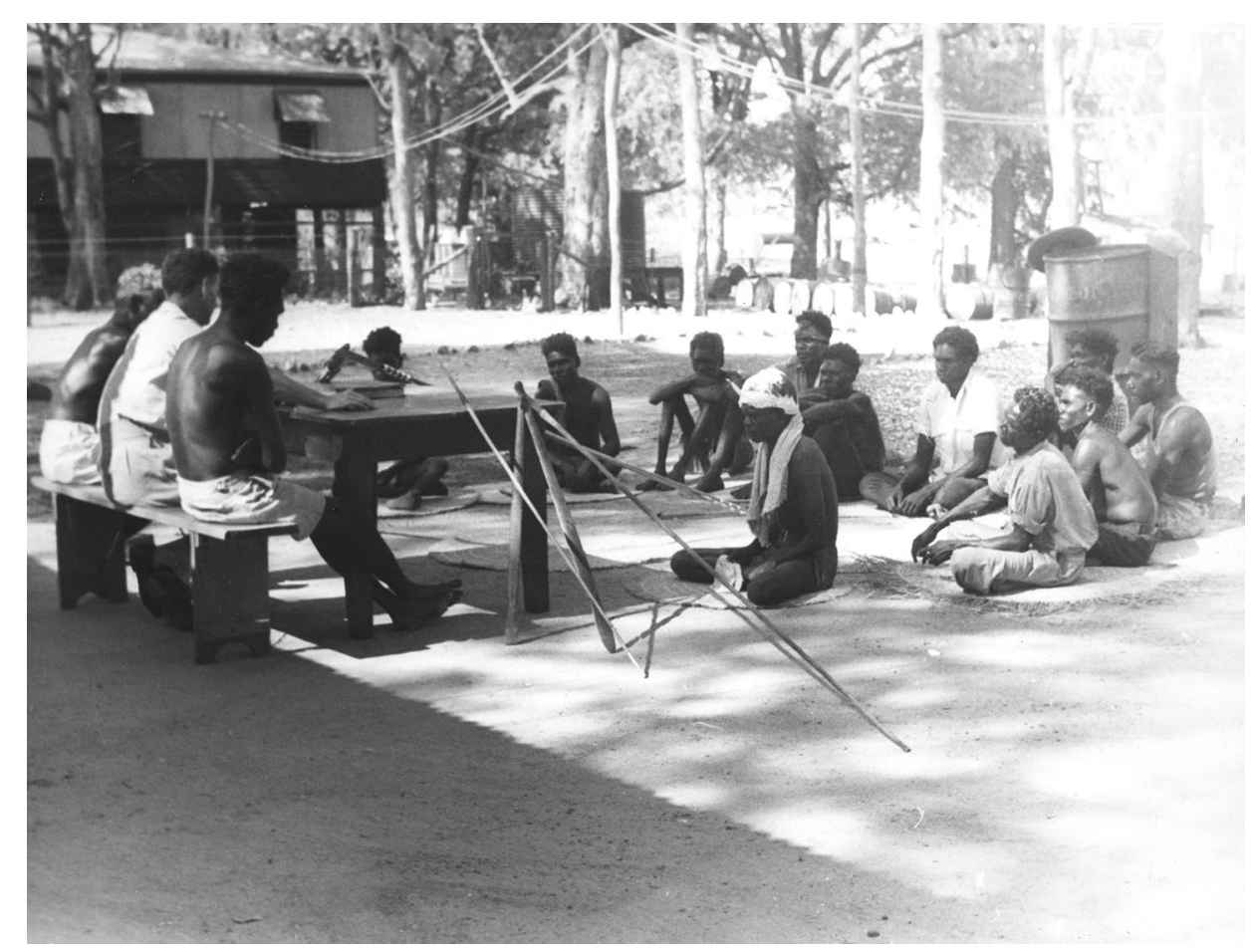

Figure 9.10 Court case for Ngalandir; Djäwa, Edgar Wells and Jacky Badaltja seated at table at Milingimbi, 1955.

Source: Frank Clune. Courtesy Kluge-Ruhe Collection, The University of Virginia. 11.03.02.023.

It was an open meeting in the open court in the community with the missionaries and the elders sitting down. They are hearing what Wells is saying. I know the story of this one but I had not seen the photos. Manymak [good] history!

The rediscovery and reinterpretation of objects like this photograph by contemporary Yolngu demonstrates the importance of kinship ties in Yolngu collection-making. For Daygurrgurr people, collected materials reaffirm the central place of Djäwa not only as an ancestor, but also as one of Milingimbi's most important leaders. 
Djäwa painted four bark paintings in the Ruhe Collection, two purchased at Milingimbi by Ruhe and two from Geoff Spence in the 1960s. Gumbula explained that Djäwa, although Yirritja, had rights to paint the Dhuwa painting of the Morning Star (1993.004.124) because it was from his mother's people, the Guyula Djambarrpuyngu family from the Barge Landing outstation at Gapuwiyak. This relationship, according to Gumbula, relates to the fact that Djäwa was a wayirri watangu, hereditary owner in Yolngu law, for Milingimbi. His mother was Djambarrpuyngu and his grandmother was Walamangu. This was a contributing factor to Djäwa remaining at Milingimbi and partially a rationale for his accepted leadership. The painting Hammerhead Shark and Stingrays (1993.0004.018), in addition to its titular animals, also depicted small fish that Dr Gumbula did not know the English names for, nor did he think his father knew at the time. However it was important for Gumbula to find this information out for the painting in order to 'make sure we have a true story for this'.

The last two paintings linked to Murayana, the malevolent ghost who, according to Ian Keen's information, 'collected honey, hunts kangaroo, eats its raw flesh, spits out blood which becomes the sunset and "its power"' (Keen 1978: 60) are Murayana-Spirit of the Dead (1993.0004.067) and The Burala Rite (1993.005.865). Spirit of the Dead is a depiction of Murayana with yams, much like the body paintings painted on Gupapuyngu men in ceremony.

The Burala Rite is a painting that has more than one story to tell. The middle of the painting contains a djalumbu, or hollow log, surrounded by burala or bull roarers; there is also a manbiri or catfish and a long-neck turtle yangara. Gumbula told us (Pip Deveson, Louise Hamby and Margo Smith) about the story of the painting that is most obvious by looking at the figurative elements: 


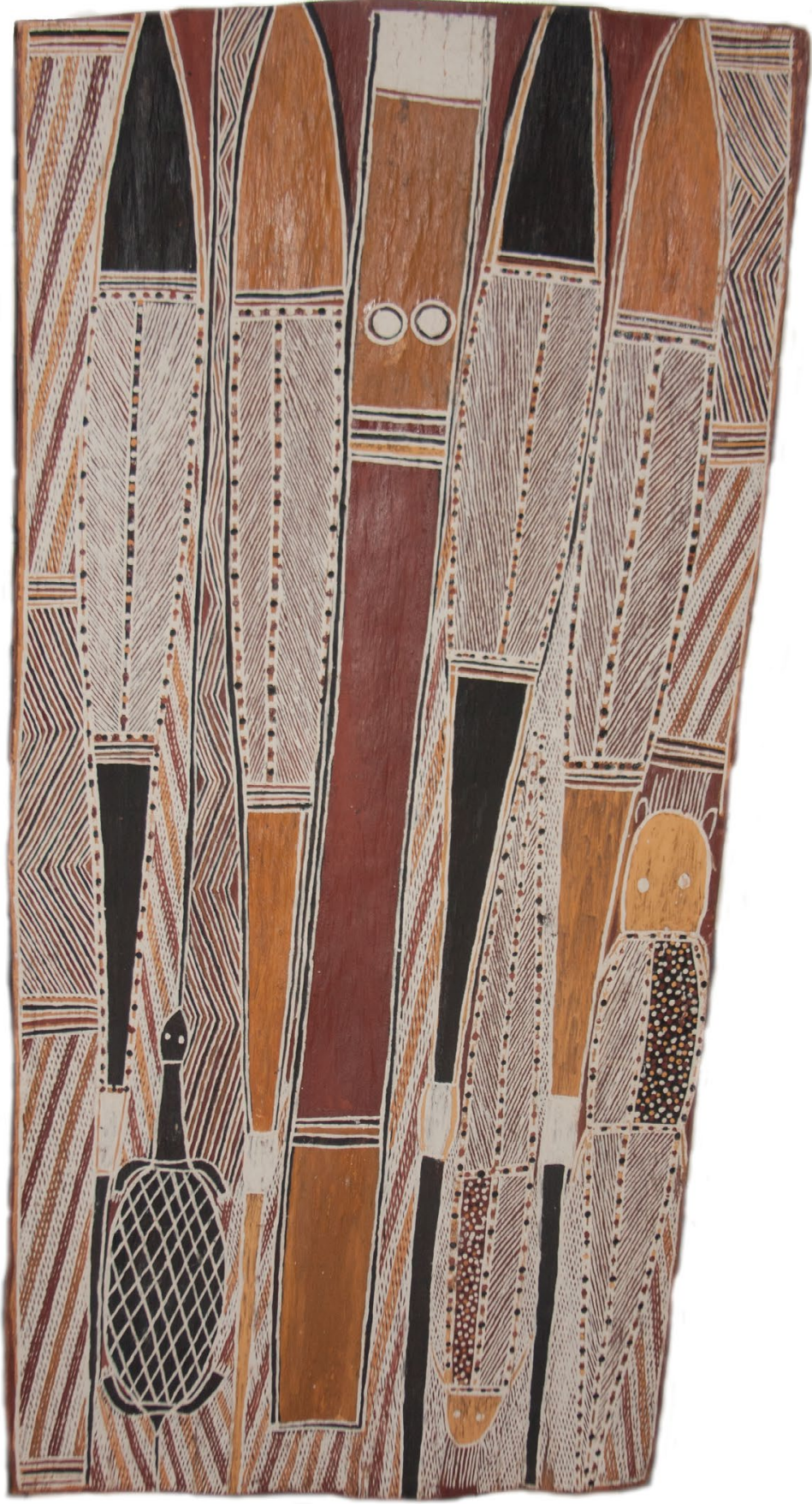

Figure 9.11 Burala Rite by Djäwa Daygurrgurr, 1972, collected by Ed Ruhe at Milingimbi.

Courtesy Kluge-Ruhe Collection, The University of Virginia. 1993.0004.865. 
We call it burala and you call it bull roarer. To represent these burala are thrown in the film that he made in 1963; that film called, titled, Djalumbu. It was in the movie thrown or done by various elders. The burala sound is like a burala diving bird coming down to the water. As they make that noise coming down with their wings. That is the significance of the sound that they do with the burala, making the sound of the bird going diving into the lake. The ancestors being giving for this side of work is Murayana; side to the Gupapuyngu nation, people.

When Smith asked Gumbula about the herringbone design on the burala she was told that it represented the bones of the catfish depicted in the painting. While contemplating the design he said: 'We got a club, bälatha. Where did we see that club? Oh, at the Smithsonian, that was painted with the same design, bälatha'. On 8 November 2010, we did look at a club (E387533) or bälatha in the Smithsonian storeroom in Maryland. Gumbula told us at the time it was made of ironwood and was a Gupapuyngu design. 'This a catfish painting, catfish bones. This is like an X-ray. I paint this. It is mambiri.' This memory and contemplation of the bones prompted Gumbula to provide us with another interpretation of the painting:

Another story was in the catfish. That was ceremony ground. This Murayana he had a lot of catfish for the day and it was piling up. So when he was eating the fish he was piling lots and lots of bones. So what he had done with the bones; he had to do something with the bones. It was storing this high. Ate a lot, and feed the family as well. There were two Murayanas, their wives and children. It was stored in a heap of bones so what Murayana recommended something about making a ceremony which was happening at the garma ground at that billabong. He went over bush and got the hollow log and took it back and disturbed the human remains. They put the bones to the fish in the entrance of the djalumbu. And they dance along the bunggul that goes with it so every time they dance they put every piece of bone through the bunggul ceremony inside.

[It] remains as a true thing what happened before. There was a ceremony like this. This is like a monument for the Gupapuyngu nation, people. When they put the bone inside somebody, so their spirit does not go dead looking through the two eyes the eyes of the deceased looking out.

Gumbula, having a great knowledge of Gupapuyngu styles, motifs and people, was able to attribute names to two painted boomerangs in the collection (1993.0004.0389 and 1993.0004.0390). He said, 'This is my detective work.' The two boomerangs, collected by Spence in 1966, were completely covered in rrark and other designs on both sides. According to Gumbula, Spence did not come to Milingimbi but collected from people when they went to Darwin. There was no documentation about the painter of the objects, but there was a note stating that they were used in ceremony. Gumbula compared these to a 
painting (1993.004.664) about the Wagilag Sisters by Lipundja \#1, his uncle. The thickness of the line in the rrark and the colour combinations were very similar. His conclusion was that the boomerangs were also painted by Lipundja.

\section{Conclusion}

The examples presented from the Kluge-Ruhe Collection are Gupapuyngu ones from the 1970s, a continuation in the long history of collecting from Milingimbi. There are others documented in this chapter that make substantial links to Gupapuyngu past history. The insights that emerged from Gumbula's engagement with his cultural patrimony in museums are that Yolngu played important roles in the formation of these collections, particularly his Daygurrgurr Gupapuyngu family, and that they reaffirm the identity of the descendants of the makers and point towards future roles they can play. As few official records exist of the roles of Yolngu at the mission, other than in employment and census records, the important relationships developed with missionaries, anthropologists and collectors, and the application of a cross-cultural research model to the materials these people collected and to their writing, has the potential to contribute significantly to the dialogue around Indigenous agency in mission history. Art, anthropology and museology present different interpretations of the same objects. At the end of the American trip Gumbula asked for a commentary for people at Milingimbi to be filmed. It sums up much of the importance of this work.

I want to explain the story as a Yolngu person. I'm talking about Yolngu thingshow we look at things ... how we want to look at the past - the Yolngu Law and stories. And it's going to take our memories back ... so we can bring the Yolngu Law into the present ... looking at it from different angles ... what information the anthropologists and researchers recorded ... about the art - the paintingsand why Yolngu gave this to them [the researchers]. So we'll see. And how our elders were doing this work. Most of this has been forgotten but some is kept by elders who are living today ... and by the balanda [Europeans]. But according to the field notes the elders didn't give much information ... when the researchers were collecting Yolngu history and information.

We have to stand on that foundation, restoring all the information about the clans. So that it will make things easier for later researchers. We have to go through the guidelines ... so people will know the correct information. If they see Djäwa's painting ... they have to put down that it was Djäwa's work, with a photograph of Djäwa. Or if it's Lipundja's painting, they'll do the same. And Mungunu - the same thing - they'll put his names. They are the sons of Narritjnarritj. So we'll be checking more information ... We have to check everything to put some things in the open access category. Like the bark paintings that were done just to get some smokes! We have to respect and recognise the elders and the people who 
worked with the researchers ... because we have to acknowledge their workto give some acknowledgement in writing for their hard work. And that's all. (Deveson 2010)

There has been a significant change in attitudes about material culture and collecting in the late twentieth century, particularly in museum practice. More emphasis has been placed on Indigenous knowledge and authority from source communities, showing that the meanings of collections are more open. The same objects can have significance in different ways. Yolngu are seeking ways of reaffirming their identity and taking an active role in how they are perceived by others. Gumbula, for example, made (with his balanda co-researchers) a virtual legacy collection of his clan and others from Milingimbi.

Time is bringing new interpretations of old materials, but in this case it is paired with relationships built over time. Ian Keen worked with Djäwa Daygurrgurr in the 1970s, examining how he and other Yolngu interpreted religious practice into political statements about their authority, and Louise Hamby worked with Dr Gumbula, the son of Djäwa, who reinterpreted materials. This work is a translation of agency-Djäwa asserting the terms of collection of objects and Dr Gumbula embedding those into the collections. In Dr Gumbula's study of Yolngu cultural materials in museum collections around the world, especially those pertaining to his own Gupapuyngu group, one can see the active and politically empowering process of forming new 'legacy collections'.

\section{References}

Arnhem Land Progress Aboriginal Corporation. 2009. Milingimbi Community.

Allen, L. 2008. Tons and tons of valuable material: the Donald Thomson collection. In N. Peterson, L. Allen and L. Hamby (eds), The Makers and Making of Indigenous Australian Museum Collections, pp.387-418. Melbourne: Melbourne University Press.

Cole, K. 1979. The Aborigines of Arnhem Land. Adelaide: Rigby.

Corn, A. and J.N. Gumbula. 2006. Rom and the academy repositioned: binary models in Yolngu intellectual traditions and their application to wider intercultural dialogues. In L. Russell (ed.), Boundary Writing : An Exploration of Race, Culture, and Gender Binaries in Contemporary Australia, pp. 170-97. Honolulu: University of Hawai'i Press.

Corn, A. and J.N. Gumbula. 2007. Budutthun ratja wiyinymirri: formal flexibility in the Yolngu manikay tradition and the challenge of recording a complete repertoire. Australian Aboriginal Studies 2: 116-26. 
Deveson, P. 2010. Gumbula commentary to Yolngu from film footage.

Groger-Wurm, H. 1973. Australian Aboriginal Bark Paintings and their Mythological Interpretation. Canberra: Australian Institute of Aboriginal Studies.

Hamby, L. 2011. The forgotten collection: baskets reveal histories. In M. Thomas and M. Neale (eds), Exploring the Legacy of the 1948 Arnhem Land Expedition, pp. 213-38. Canberra: ANU E Press.

Herzmark, M. 1972. The Arnhem Land Painters. Television Services.

Kadiba, J. n.d. Webb, Thomas Theodor (1885-1948). Australian Dictionary of Biography Online Edition. Retrieved from adb.anu.edu.au/biography/webbthomas-theodor-11990.

Keen, I. 1977. Ambiguity in Yolngu religious language. Canberra Anthropology 1: 33-50.

Keen, I. 1978. One Ceremony, One Song: An Economy of Religious Knowledge among the Yolngu of North-East Arnhem Land. PhD Thesis, The Australian National University, Canberra.

McCulloch, S. 2011. Buku-manapanmirr: Meeting Together and Sharing Yolngu Knowledge and Culture. Exhibition brochure, Woolloongabba Art Gallery.

McKenzie, M. 1976. Mission to Arnhem Land. Adelaide: Rigby.

Milliken, E.P. 1972. Permit to enter Arnhem Land. 7 April.

Mundine, D. 2000. The native born. In B. Murphy (ed.), The Native Born: Objects and Representations from Ramingining, Arnhem Land, pp. 29-111. Sydney: Museum of Contemporary Art.

Mundine, D. 2004. Some people are stories. In S. Jenkins (ed.), No Ordinary Place: The Art of David Malangi, pp. 29-41. Canberra: National Gallery of Australia.

Peterson, N., L. Allen and L. Hamby. 2008. Introduction. In N. Peterson, L. Allen and L. Hamby (eds), The Makers and Making of Indigenous Australian Museum Collections, pp. 1-26. Melbourne: Melbourne University Press.

Risemen, N. 2008. Disrupting assimilation: soldiers, missionaries and Aboriginal people in Arnhem Land during World War II. In A. Barry, J. Cruikshank, A. Brown-May and P. Grimshaw (eds), Evangelists of Empire? Missionaries in Colonial History, pp. 245-62. Melbourne: University of Melbourne eScholarship Research Centre. 
Ruhe, E. 1971a. Letter to Ted Milliken. Kluge-Ruhe Archives, University of Virginia.

Ruhe, E. 1971b. Letter to B.A. Clarke, 13 December. Kluge-Ruhe Archives, University of Virginia.

Satterthwait, L. 2008. Collections as artefacts: the making and thinking of anthropological museum collections. In N. Peterson, L. Allen and L. Hamby (eds), The Makers and Making of Indigenous Australian Museum Collections, pp. 29-60. Melbourne: Melbourne University Press.

Setzler, F. 1948. Groote Eylandt to Yirrkala to Milingimbi [Diary, vol. 2]. Canberra: National Library of Australia.

Shepherdson, E. 1981. Half A Century in Arnhem Land. One Tree Hill, SA: Ella and Harold Shepherdson.

Smith, M. 2008. Aesthete and scholar: two complementary influences on the Kluge-Ruhe Aboriginal Art Collection of the University of Virginia. In N. Peterson, L. Allen, and L. Hamby (eds), The Makers and Making of Indigenous Australian Collections, pp. 556-79. Melbourne: Melbourne University Press.

Tamisari, F. and E. Milmilany. 2003. Dhinthun wayawu - looking for a pathway to knowledge: towards a vision of Yolngu education in Milingimbi. The Australian Journal of Indigenous Education 32: 1-10.

Tamisari, F. 2005. The responsibility of performance: the interweaving of politics and aesthetics in intercultural contexts. Visual Anthropology Review 21(1-2): 47-62.

Trudgen, R. 2000. Why Warriors Lie Down and Die: Towards an Understanding of Why the Aboriginal People of Arnhem Land Face the Greatest Crisis in Health and Education Since European Contact. Darwin: Aboriginal Resource and Development Services Inc.

Warner, W. L. 1969. A Black Civilization: A Social Study of an Australian Tribe. Revised edition. New York: Harper and Brothers.

Wearing, B. 2007. Beulah Lowe and the Yolngu People. Glenning Valley, NSW: Betsy Wearing.

Wells, A. 1963. Milingimbi: Ten Years in the Crocodile Islands of Arnhem Land. Sydney: Angus and Robertson.

Wells, E. 1982. Reward and Punishment in Arnhem Land 1962-1963. Canberra: Australian Institute of Aboriginal Studies. 
Wilkins, C.S.G.H. 1929. Undiscovered Australia. London: G.P. Putman's Sons.

Yolngu follow father's footsteps. (2011, July 12). The Chronicle. Toowoomba, NSW. Retrieved from www.thechronicle.com.au/news/yolngu-followfathers-footsteps/903562. 
This text is taken from Strings of Connectedness: Essays in Honour of Ian Keen, edited by Peter Toner, published 2015 by ANU Press, The Australian National University, Canberra, Australia. 